\title{
Retelling the history of Manipur through the narratives of the Puyas
}

\author{
Rosy Yumnam*
}

\begin{abstract}
Reception of memory occupies a critical role in the area of memory studies. Historical studies of memory accounts for the analysis of the textual, visual or oral representations of the past. History and memory are expressed in multiple voices and the reinterpretations of the past can be varied. However, construction of historical memory is a tedious process for the lack of evidences. Most importantly in the ever-changing dynamics of history and memory, it is essential to know what has been lost to reconstruct the culture, language and history of a society. Relatedly, the use of narrative in history is pertinent in the process of the construction of historical memory. The Puyas are the ancient written texts of the Meiteis, i.e. one of the ethnic groups of Manipur, a state in India. The study focuses to reinvent or to bring back into existence a lost ethos by a collective effort of rediscovering the Puyas from all sections of the Meitei society. Exploring the narratives of the Puyas, the paper seeks to capture the collective memory of the Meiteis into retelling the history of Manipur. The paper further examines the various challenges encountered in constructing the historical memory through the Puyas.
\end{abstract}

Key words: Meiteis, Puyas, Manipure , Meitei Mayek

* The English and Foreign Languages University, Shillong Campus. Email: rosy@eflushc.ac.in 
JHSS, Vol. 11, No. 2, July to December, 2020

\section{INTRODUCTION AND BACKGROUND}

The Puyas are literary pieces which deal with varied subjects like medicine, religion, code of warriors, rites and rituals, migration, history, astronomy, political, manuals of administration, natural phenomena, etc. They were written in an ancient script called Meitei Mayek. Some of the materials employed for writing the Puyas were jute fiber, bamboo pulp, palm leaves, Tengna (a local grass), agar wood and copper plate. The dates of the existence of the Puyas are still refutable, however, they serve as a vital component in the study of history of Manipur as archaeology and historiography developed at a later stage. They can be traced as early as the eighth century A.D. though the dates are still refutable. Singh asserted that the writing in Meitei Mayek started most likely towards the end of the twelfth century and it is definitely not after the fifteenth century. ${ }^{1}$ In addition to the above arguments, Laisram is of the view that the literary culture of Manipur is believed to have started to develop during the time of King Khagemba $(1597-1652){ }^{2}$ More than 4000 Puyas are available till date. Till the seventeenth century, the Puyas were anonymously written and undated. The language and style of the Puyas are used to find out the chronology of the narratives. Many of the Puyas which are available are transliterated from Meitei Mayek into modern Manipuri script and very few have been attempted to translate in English. The Puyas form the cultural narratives of the Meitei community. They reflect how life, values and traditions, cultural identity and society were formed, developed and sustained. The Puyas have played a vital role in capturing the collective shared experiences of the Meitei culture and civilization. Therefore, they can be viewed as a significant aspect in retelling the history of Manipur.

\section{Narrative and History}

Narrative encompasses every realm of history. In this context, Munslow contends that narrative is fundamental to historical explanation and it serves as the source for the representation and creation of historical knowledge and explanation. ${ }^{3}$ To a historian, a narrative is an act of telling an event or events by a narrator to a narratee in a jargon-free language. ${ }^{4}$ Further, he argues, "The historical narrative , because it is composed within the realist mode, is normally invested with a naturalism concerning truth that more obviously fictional narratives do not claim - although there is a substantial contemporary debate about the truth-carrying characteristics of fictional narrative". It is therefore, evident that narrative plays an important role in creating and telling history. Relatedly, the function of memory plays a vital role in the studies related to memory and reconstruction. As Hamilton observes, the content of history can be considered to include the tropes used by history through its various narratives and the realism which connects the present and the past. ${ }^{6}$ An investigation of the visual, oral or textual representations of the past are accounted in the study of historical memory. Further, the expression of multiple narratives of history and memory includes the oral cultures also. As Cobley states that in cultures where writing is not available, the process of narrative assists in tracing and keeping alive the memory

1 Ch. Manihar Singh, A History of Manipuri Literature, Sahitya Akademi, 2004.

2 Rena Laisram, Early Meitei History: Religion, Society and the Manipur Puyas. Akansha Publishing House, 2009.

3 Alun Munslow, The Historical Companion to Historical Studies. Routledge, 2006. p.180

4 Ibid., p. 180

5 Ibid., p. 180

6 Knellwolf, Christa \& Norris Christopher (ED.). The Cambridge History of Literary Criticism, Volume 9.

Cambridge University Press, 2001.p.17 
which further help in preserving the customs, traditions and history of the lives of the people. ${ }^{7}$ Furthermore, Cobley observes cultures which possess writing can definitely account and create scientific or abstract works but oral culture is devoid of this important aspect of maintaining the records. ${ }^{8}$ Therefore, for the oral cultures they rely on, "stories of human action to store, organise and communicate what they know". ${ }^{9}$ From the above discussions, it is imperative that narrative is a vital source for connecting to past events both in written and the oral forms. Narrative describes stories of a group of people in a community relating to its historical development. The invincible narrative of the Puyas captures the vital myth, oral traditions, religion, social, political and historical aspects which include the representations of the oral cultures reminiscent of the Meiteis through the medium of folk culture and oral traditions like prose, songs, proverbs, maxims, and verses.

\section{Objectives}

As the Puyas are narratives accounting the culture, myth, social, political and history of the Meitei community, a thorough research into understanding its narratives is required. Therefore, an analysis of the narratives of the Puyas has been taken up to understand the rich cultural, social and historical traditions of the Meitei community. The paper aims to capture the collective memory of the Meiteis into retelling the history of Manipur by exploring the narratives and oral cultures ubiquitous in the Puyas.

\section{METHODOLOGY}

The study adopted an analytical method. For this, the readings of primary, secondary sources, research journals and online sources have been taken up.

\section{FINDINGS AND DISCUSSIONS}

\section{The Puyas and the Early Meitei History}

The Puyas deal with varied subjects encompassing the overall existence and functioning of the society which plays a crucial role in tracing the history of Manipur. Some of the Puyas can be seen to cover multiple subjects on a common theme. The Puyas such as Khamlangba Erengba Puwari, Leithak Leikharon and Pudin covers the theme of creation and cosmology as well as archiving the history of the clan system of the Meitei community. ${ }^{10}$ In the pre-Hindu period, the Meitei community believed in ancestor worship which heralds the philosophy and the religious system of the Meiteis. Laisram is of the view that the ancient Meitei religion endured and came a long way even when Vaishnavism was declared as the state religion of Manipur in the eighteenth century. ${ }^{11}$ Some of the Puyas like Thalloi Nongkhailon, Erat Thounirol, Sanamahi, Pakhangba Laihui, and Panthoibi Khongul and Sakok Lamlen Ahanba chronicled the rites, rituals, philosophy of religion and the myths associated with the worshipping of Gods and Goddesses. ${ }^{12}$

7 Paul Cobley, Narrative: The New Critical Idiom. Routledge, 2014. p.31

8 Ibid., p.32

9 Ibid., p.32

10 Op.Cit., Laisram, 2009, p.19

11 Ibid., p. 66

12 Ibid., pp.19-21 
The Puya, Leithak Leikharon describes Sanamahi as Asheeba who created the universe with all the living beings with assistance from the Almighty, Taibangpanba Mapu. Accordingly, Sanamahi is thus believed to be the creator of the entire universe and the most important God in the Meitei pantheon. The myth involving Lord Sanamahi is chronicled in the Puya, Sanamahi Laihui and so it acts as a vital source for the revival of the indigenous Sanamahi religion of the Meiteis. It is thus observed that the Puyas have played a crucial role in the revival of the indigenous religion of the Meiteis called the Sanamahi religion. This in turn is vital in retelling the history of Manipur.

Relatedly, the Puyas have played a significant role in ascertaining an oral mnemonic structure of the Meitei community. A very important religious and social festival of Manipur is the Lai Haraoba festival where the revered ancient spirits, Umanglais are venerated. The religious rites, rituals and the cultural practices of the Lai Haraoba festival have been recorded in the Puyas, Lai Khunta Lon Puya, Leithak Leikharon and Panthoibi Khongul. Hijan Hirao is another Puya representing the poetic traditions of the Meiteis. It is sung on the last day of the Lai Haraoba festival showing the incorporative nature of narratives and oral cultures. The preceding discussions, therefore, details the role of the Puyas in conserving and safeguarding the traditions, customs, religious and social practices of the Meitei existence. This in turn has created a fundamental role in recapturing the history of the Meitei existence.

Through narratives, history encompasses both the past and the real. History not only narrates stories from the past but it also serve as a medium to store knowledge. In this regard, Munslow avers that history is described as a narrative representing the reality of the past that distinguished "the sequential and temporal relationships" " which is seen in 'the real', 'the story' and 'it's telling'. ${ }^{14}$ Narrative therefore plays a crucial role in telling story which in the course of time becomes significant in creating historical knowledge. The Puya, Cheitharol Kumbaba/ Cheitharon Kumpapa plays a significant role in telling and constructing historical memory. The historical events of seventy-eight kings starting from the first historical king, Nongda Lairen Pakhangba (33-154 A.D.) to Bodhachandra Singh (1941-1955) is believed to have been chronicled in Cheitharol Kumbaba. ${ }^{15}$ The chronicle of about eight hundred pages cited the beginning of the counting of years called Cheithaba in 1485 A.D. by King Kyamba ${ }^{16}$ So, the historical events have been recorded with days of the week and the corresponding dates and months. It is believed that the accounts before that were reconstructed out of available sources. The writing of Cheitharol Kumbaba commenced during the reign of King Kyamba. Cheitharol Kumbaba begins with the lines:

With due obeisance to the Lord of the Universe let Cheitharol Kumbaba (Royal Chronicle) be written for which may there be no spite.

..... Pakhangba reigned for 120 years and the counting of the year known as Sakabda (Saka) commenced from the 45 th year of his reign. ${ }^{17}$ Thus, there is a record of King Nongda Lairen

13 Alun Munslow, Narrative and History. Palgrave Macmillan, 2007. p.17

14 Ibid., p.17

15 Op.Cit., Lairsram, p.20

16 Ibid.,

17 Bihari Nepram, (ed. \& tr.) The Cheitharol Kumbaba: The Royal Chronicle of Manipur. Spectrum Publications,

2012, p.31 
Pakhangba or Pakhangba to have been the first historical king to have ruled Manipur for a glorious 120 years. Furthermore, an account of King Thawanthaba who reigned between 11171153 (1195-1231) A.D. / C.E. has been chronicled in Cheitharol Kumbaba as follows:

Meidingu Thawanthaba became the King in 1117 Saka. He invaded Chingshong tribal village and brought Leimu Yangtak as prisoner of war and the village was burnt. He conquered Koiching Koimahou and captured its headman, Thawa Lanchengshoi. Henceforth the King's name was known as Thawanthaba. ${ }^{18}$

The preceding extract describes the brave Meitei king, Meidingu (King) Thawanthaba's invasions to various villagers and under one such expedition, he captured the headman, Thawa Lanchengshoi of the village, Koiching Koimahou. From this victory, the king came to be known as Meidingu Thawanthaba. The accounts of the experienced warfare and victories of King Thawanthaba are described in detail in the Puya, Thawanthaba Hiran. As Bazerman asserts that a text is created based on the text that is already available and the comprehension of the text is apprehended within the same context. ${ }^{19}$ This asserts the interconnection of one text with that of the other. The language and style of Cheitharol Kumbaba suggests that it started chronicling the historical events from around fifteenth century A.D. Cheitharol Kumbaba describes the umpteen proceedings and events of the kings like their military sojourn, accession to the throne, religious, traditional and social rituals and customs, the migrations of Muslims to Manipur, the visits of holy men to Manipur, religious conversions, natural calamities and many encyclopedic information.

As has been observed by Kabui the reconstruction of the early period of the history of Manipur was founded on the accounts of the Ningthouja clan supported by other clans and some literary sources. The Meitei clan system is called sagais and constitute of seven clans. They are Ningthouja, Angom, Chengloi, Nganba, Luwang, Khuman and Moirang. Some other clans like Mangang, Mangding, Chiren, Khende, Hairen Khunju, etc., can also be found but in the course of time have been merged into the seven clans. This Meitei clan system has been identified after a thorough study of the Puyas such as Wakoklon Hilel Thilel Amailon Pukok, Leithak Leikharon and Sakok Lamlen Ahanba. In this way, the Puyas have played an important role for the Meiteis to connect with the past events socially, politically and historically. ${ }^{20}$

\section{The Puyas and the History of Meitei Mayek}

Language acts as a crucial cultural component for a community to exist. Pollock asserts that culture can signify language as it is considered as one of its features therefore this language is again related to literature. ${ }^{21} \mathrm{He}$ further states that literary culture is the practice where the distinct unit of language is used to create literatures within a political and social context. ${ }^{22}$ This explains the close interrelationship between literature, language and culture. It also explains that the

18 Ibid.,31

19 Charles Bazerman, "Intertextuality: How texts rely on other texts", in What Writing Does and How it does it: An Introduction to Analysing Texts and Textual Practices. (eds.) Charles Bazerman and Paul Prior. Lawrence Erlbaum, 2004, pp. 83-96

20 Gangmumei Kabui, History of Manipur. National Publishing House, 1991

21Sheldon Pollock, The Language of the Gods in the world of Men. Permanent Black, 2007.p.2

22 Ibid., p. 2 
language of the literary text describes the political and social milieu and further shapes the history of the society. It is thus evident that language is the basic source which helped people bond with the past events. Manipur boasts of various culturally distinct ethnic groups which contribute to the history of its civilization. Manipuri language is used as a lingua franca of the plains and the hill people of Manipur. Manipuri language has been included in the eighth schedule by the 71st amendment of the Indian Constitution in 1992. The people of Manipur use two writing systems which are, Manipuri, written in Meitei Mayek before nineteenth century and Modern Manipuri, written in Bengali script in the later part of eighteenth century. The spoken Manipuri is same in both ancient and modern. However, only the written script differs. Laisram observes that the study of the migration of the Brahmanas plays an important role in the history of Manipur as it details the gradual transformation of the religious history of the Meiteis from ancestor worship to Hinduism. ${ }^{23}$ Cultural pluralism can be observed with the advent of Hinduism among Meiteis during King Pamheiba's (1709-1748) reign. ${ }^{24}$ The unfair mass burning of the Puyas called Puya Mei Thaba in 1732 at King Pamheiba's (also called King Garibniwaz) order in the process of embracing Hinduism induced the near extinction of the ancient script, Meitei Mayek. The Puya, Cheitharol Kumbaba has recorded the incident as, in the year 1732 A.D., on the 17th day Sunday, King Garibniwaz under the guidance of Guru Santidas sent message to collect all the old manuscripts from the nook and corners of the kingdom and destroy them by burning it in front of Kangla Uttra of the royal palace. ${ }^{25}$ As a result, Meitei Mayek was replaced by Bengali script while writing the Manipuri language. Slowly, the Puyas disappeared from the public. Thereafter, Hindi and other Indian cultural influences can be seen in the life of the Meiteis especially after Manipur was merged into the Dominion of India in the year $1949 .{ }^{26}$ The revival of Meitei Mayek started from around the 1940s. Meitei Mayek with 18 alphabets was finally reinvented and this was possible by a meticulous study of the Puyas such as Wakoklon Thilel Salai Amailon Pukok and Wakoklon Thilel Salai Singkak. The present Meitei Mayek contains 27 basic letters as 9 letters which are derivatives of the previous 18 alphabets were added. The Government of Manipur has recognized the alphabet with 27 letters in the year $1980 .{ }^{27}$ The reinvention and reconstruction of the Meitei Mayek is a great achievement of the Meiteis as this paves the way for a revival of their lost traditions and culture and this was observed with the introduction of a Meitei Mayek text book called Meetei Mayek Tamnaba Mapi Lairik for students of class VI by the Education Department of the Government of Manipur in 1983. More recently Meitei Mayek is studied as a part of academic curriculum in the schools and colleges of Manipur. The success of the reconstruction of Meitei Mayek is a result of a religiously thorough research of the Puyas. It is thus evident that the revival of the ancient script, Meitei Mayek has assisted in tracing and retelling the history of the civilization of the Meitei community.

\section{Challenges in Reconstructing the Puyas}

Historians have often been skeptical about the information which is recorded without references. Lack of evidences and validations are a big setback in reconstructing a lost culture. As Puyas are written narratives without proper validations, it has become a daunting task for the scholars in its

23Op.Cit., Laisram, 2009, p.22

24 Irengbam, Arun. (ed.) Chainarol (Way of the warrior). Human Rights Alert, 2012.p8

25 Op.Cit., Laisram 2009, p.13

26 Op.Cit., Irengbam 2012, p. 8

27 Manipur Gazette, No. 33, 1980 
reconstructing process. Moreover, many of the Puyas writing on a particular theme tend to touch upon various other subjects. As Laisram states that a Puya having a creation myth as its theme may also chronicle other themes like charms and rituals, religious philosophy, genealogy, etc. ${ }^{28}$ This aspect of the Puyas becomes difficult for the scholars to formulate a historical construct. So, a comparative study of the various Puyas is important to retrace the myths, facts, traditions, folklore, etc. Futhermore, the Puyas are revered as a sacred text. They are untouched, guarded and given a special place at the home of the custodians. They were allowed to be brought out only on auspicious days. The Puyas mentioned that dishonest and sinful person should not touch the Puya. Even to read a Puya one has to perform certain rituals like taking bath, changing into fresh clothes, lighting lamp and burning incense sticks. Moreover, the custodians of the Puyas were not ready to part with it as they believe that something bad would befall them. The infamous Puya Meithaba (Mass burning of Puyas) of 1732 played a crucial role in the disappearance of the Puyas. ${ }^{29}$ It is learned that many of the Puyas which are believed to have been burned are still found intact. Many of them were kept hidden in secret places by the custodians for the fear of oppressions by the Meitei kings.

Conversely, many of the Puyas came to the open as a result of the revival of the Sanamahi religion among the Meiteis. ${ }^{30}$ These Puyas are then collected by the Manipur State Archives, State Kala Academy, libraries and many other such organisations. The inadequate reconstruction and documentation of the Puyas was mainly because of the fact that the initial contributors who are associated with this daunting task of reconstruction were the non-Meitei writers who were not able to handle the Puyas. ${ }^{31}$ However, she points out that the works of the British political agents like, Brown, Pemberton, Dun McCulloch and T.C. Hodson written in English formed the major source of early history and ethnography of Manipur. ${ }^{32}$ In the seven years of war (18191825 A.D.) fought between Manipur and Burma, Manipur was disastrously defeated. The defeat led to the capture of many Meiteis in Burma who took away the Puyas with them. These are some of the reasons for the unavailability of the Puyas.

\section{CONCLUSION}

The deliberations, therefore, contends that the historical memory of the Meitei community are entrenched in the myths, legends, folklores, traditional religious practices, etc. manifested in the Puyas. As the content of history includes various narratives connecting the present and the past, therefore, the collective experiences of the Meiteis defined in the Puyas assisted in strengthening the process of restructuring and reconstruction. Munslow's contention that narrative is fundamental to historical knowledge and explanation is pertinent as the narratives of the Puyas have been found to represent and recreate the Meitei historical knowledge. ${ }^{33}$ The Puyas, therefore have played a crucial role in retelling the past events through rediscovering a lost narrative and restructuring the social, cultural, religion and language of the Meiteis into a new historical approach.

28 Op.Cit., Laisram, 2009, p.12

29 Ibid., p.13

30 Ibid., pp.14-15

31 Ibid., p.15

32 Ibid., 15

33 Op.Cit., Munslow, 2006 
JHSS, Vol. 11, No. 2, July to December, 2020

\section{REFERENCES}

Annenberg Learners Editors. History and Memory. Bridging World History, 2016, http://www.learner.org/courses/world history/unit_overview_2.html

Bazerman, Charles. "Intertextuality: How texts rely on other texts", in What Writing Does and How it does it: An Introduction to Analysing Texts and Textual Practices. (eds.) Charles Bazerman and Paul Prior. Lawrence Erlbaum, 2004, pp. 83-96

Cobley, Paul. Narrative: The New Critical Idiom. Routledge, 2014

Hodson, T. C. (Reprint). The Meitheis, Akansha Publishing House, 2016

Human Rights Alert. Chainarol (Way of the Warrior). Human Rights Alert, 2012.

Irengbam, Arun. (ed.) Chainarol (Way of the warrior). Human Rights Alert, 2012

Kabui, Gangmumei. Colonial and Post-Colonial Historiography of Manipur. Journal of North East India Studies, 2012, http://www.jneis.com/

Kabui, Gangmumei. History of Manipur. National Publishing House, 1991

Knellwolf, Christa \& Norris Christopher (ED.). The Cambridge History of Literary Criticism, Volume 9. Cambridge University Press, 2001.

Laisram, Rena. Early Meitei History: Religion, Society and the Manipur Puyas. AkanshaPublishing House, 2009.

Lisham Tomba Singh \& P. Madhubala. Manipuri (MeeteiMayek) Writing System, 2013,www.iosrjournals.org

Munslow, Alun. Narrative and History. Palgrave Macmillan, 2007.

Munslow, Alun. The Historical Companion to Historical Studies. Routledge, 2006.

Naorem, Sanajaoba. Manipur Past and Present Volume I. Mittal Publications, 1988.

Naorem, Sanajaoba. Manipur Past and Present Volume II. Mittal Publications, 1991.

Naorem, Sanajaoba. Manipur Past and Present Volume III. Mittal Publications, 1995.

Nepram, Bihari. (ed. \& tr.) The Cheitharol Kumbaba: The Royal Chronicle of Manipur. Spectrum Publications, 2012.

Paniker K. Ayyappa. Medieval Indian Literature: An Anthology Volume III. Sahitya Academi, 1999. 
Retelling the History of Manipur through the Narratives of the Puyas

Pollock, Sheldon. The Language of the Gods in the world of Men. Permanent Black, 2007.

Sadokpam, Dhiren. History of MeeteiMayek,2003, http://www.unicode.org/L2/L2000/00259MeeteiMayek.pdf

Singh, Ch. Manihar. A History of Manipuri Literature. Sahitya Akademi, 2004.

Singh, N. Khelchandra. Significance of Kangla in the Economic History of Manipur, 1999-2000, http://books.e-pao.net/heritage_manipur/epShowChapter.asp?src=kangla

Timmins, Adam. Review of Memory and History: Understanding Memory as Source and Subject, 2016, http://www.history.ac.uk/reviews/review/1470 